\title{
Searching for synthetic mechanisms on how biological traits mediate species responses to climate change
}

\author{
Fábio Júlio Alves Borges $^{1^{*} \text { (D) }}$ \& Rafael Loyola ${ }^{2,3}$ \\ ${ }^{1}$ Universidade Federal de Goiás, Programa de Pós-graduação em Ecologia e Evolução, Goiânia, GO, Brasil. \\ ${ }^{2}$ Universidade Federal de Goiás, Departamento de Ecologia, Goiânia, GO, Brasil. \\ ${ }^{3}$ Fundação Brasileira para o Desenvolvimento Sustentável, Rio de Janeiro, RJ, Brasil. \\ *Corresponding author: fabiojaborges@gmail.com
}

BORGES, F.J.A., LOYOLA, R. Searching for synthetic mechanisms on how biological traits mediate species responses to climate change. Biota Neotropica 21(3): e20211204. https://doi.org/10.1590/1676-0611-BN-2021-1204

\begin{abstract}
Climate change will likely be the most significant challenge faced by species in this century, and species' ability to cope with climate change depends on their life history and ecological and evolutionary traits. Understanding how these traits mediate species' responses is beneficial for identifying more vulnerable species or prone to extinction risk. Here, we carried out a literature review describing how four traits commonly used in vulnerability assessments (i.e. clutch size, diet breadth, dispersal ability, and climatic tolerance) may determine species vulnerability. We also portray the possible mechanisms that explain how these traits govern species responses to climate change. The literature suggests different mechanisms operating for the evaluated traits. The mechanism of response to climate change differs between species inhabiting tropical and temperate regions: while species from the temperate areas may respond positively to temperature rise, tropical species may be severely affected. Since ectotherms depend on environment temperature, they are more sensitive and present different response mechanisms from endotherms. Keywords: Global warming; extinction risk; phenology; physiology; species traits.
\end{abstract}

\section{Em busca de mecanismos sintéticos sobre como os atributos biológicos mediam as respostas das espécies às mudanças climáticas}

\begin{abstract}
Resumo: A mudança climática provavelmente será o maior desafio enfrentado pelas espécies neste século e a capacidade das espécies em lidar com a mudança climática depende de seus próprios atributos de história de vida, ecológicos e evolutivos. Entender como esses atributos mediam as respostas das espécies é extremamente útil para identificar espécies que são mais vulneráveis ou sujeitas ao risco de extinção. Aqui, realizamos uma revisão da literatura com foco na descrição de como quatro atributos comumente usados em avaliações de vulnerabilidade (tamanho da ninhada, amplitude da dieta, capacidade de dispersão e tolerância climática) podem realmente determinar a vulnerabilidade das espécies. Também retratamos os possíveis mecanismos que explicam como esses atributos governam as respostas das espécies à mudança climática. A literatura sugere diferentes mecanismos operando para os atributos avaliados. $\mathrm{O}$ mecanismo de resposta à mudança climática difere entre as espécies que habitam as regiões tropicais e temperadas: enquanto as espécies das regiões temperadas podem responder positivamente ao aumento da temperatura, as espécies tropicais podem ser severamente afetadas. Como os ectotérmicos dependem da temperatura ambiente, eles são mais sensíveis e apresentam mecanismos de resposta diferentes dos endotérmicos.
\end{abstract}

Palavras-chave: Aquecimento global; risco de extinção; fenologia; fisiologia; atributos das espécies. 


\section{Introduction}

Climate change will likely be the most significant challenge faced by species this century. The observed effects include changes in distribution areas, phenology, morphology, demography, and abundance (Parmesan and Yohe 2003; Parmesan 2006; Lane et al. 2012). Species ability to respond to climate change depends on their life-history traits (Végvári et al. 2010; Angert et al. 2011; Pacifici et al. 2017), which can help predict species that will be more vulnerable and direct conservation efforts (Foden et al. 2013).

In this sense, the use of trait-based Climate Change Vulnerability Assessments (CCVAs) has become popular in studies that assess climate change impact on species vulnerability (Foden et al. 2018). In the context of CCVAs, the term "trait" refers to a wide range of species characteristics (such as diet breadth and climatic tolerance) instead of referring to specific features of an individual (sensu Violle et al. 2007). Trait-based CCVAs combine scores based on exposure to climate change (extrinsic factors) with biological characteristics of species (intrinsic factors), which define their sensitivity and adaptive capacity to obtain a general measure of vulnerability (Pacifici et al. 2015).

Vulnerability is assessed based on these three components: exposure, sensitivity, and adaptive capacity, so that species with high exposure, high sensitivity, and low adaptive capacity will be the most vulnerable to climate change (Dawson et al. 2011; Foden et al. 2013). Exposure is determined by the rate and magnitude of climate change within the species' distribution area. Sensitivity is characterised by the ability to tolerate climate change and is generally associated with physiological tolerance and habitat specialisation. Adaptive capacity refers to the ability of a given species to deal with climate change, whether adapting to new local conditions or dispersing to more suitable areas (Dawson et al. 2011).

Despite the importance of biological traits in determining species vulnerability, there is no agreement on which traits should be used in assessments. Their selection depends on data availability and the opinion of experts (Foden et al. 2013, 2018). Biological traits may help identify species with higher extinction risk (Mckinney 1997; Purvis and Hector 2000). However, species responses depend on the type of threat they are exposed to (González-Suarez et al. 2013). Species that present larger body size is more threatened by hunting, while smaller and ecologically specialised species are more threatened by habitat loss and fragmentation (Owens and Bennett 2000; González-Suarez et al. 2013).

Under the threat of climate change, biological traits might play a fundamental role in species responses, influencing their vulnerability (Jiguet et al. 2007; Angert et al. 2011; Estrada et al. 2015). Clutch size is strongly influenced by climatic variables (Jetz et al. 2008), and species may present rapid physiological adjustments of this trait in response to climatic changes (Baker 1995; Coe and Rotenberry 2003). Species that reproduce frequently or prematurely, with high fecundity, should have greater opportunities to colonise new environments (Angert et al. 2011). Species with generalist diets can change their feeding habits to other resources when climate affects the availability of preferred items (Rubolini et al. 2003; Bojarska and Selva 2012) and, consequently, they might have a higher ability to change their distributions to follow suitable climatic conditions (Angert et al. 2011). Dispersal ability is a crucial trait that allows species to change their distribution areas to follow a suitable climate. Species with higher dispersal ability might respond more quickly to climate change, facing lower extinction risk (Pöyry et al. 2009; Corlett and Westcott 2013). Species that can physiologically tolerate higher climatic variation and live in environments where temperatures are far from their upper thermal limit will be more likely to persist under climate change (Deutsch et al. 2008; Huey et al. 2012). There is a growing interest in using biological traits to assess species vulnerability in response to climate change (Gardali et al. 2012; Foden et al. 2013; Garcia et al. 2014; Böhm et al. 2016; Reside et al. 2016; Borges et al. 2019). However, potentially important traits from some taxa are still frequently unavailable, which leads to the use of morphological proxies, measurements from congeneric species or the knowledge of experts (Foden et al. 2013, 2018).

Identifying the most informative traits and responding to climate change is a priority if we want to assess the vulnerability of different species groups. However, a study showed that less than half of the studies that evaluated the relationship between traits and changes in species distributions have specified hypothesis for the ecological processes involved in the relationship (Estrada et al. 2016). To advise appropriate conservation measures, it is essential to explain the reasons for choosing traits and the specific mechanisms underlying climate change impacts on species of interest (Foden et al. 2018).

We did a literature review to understand how four traits (clutch size, diet breadth, dispersal ability and climatic tolerance) might determine species vulnerability. We also aimed to describe the possible mechanisms that explain how traits influence species responses to climatic changes. Specifically, our goals were: 1) to verify whether it is possible to use the four chosen traits to understand the mechanisms underlying the impacts caused by climate change based on the ecology literature produced so far, and 2) to present and explain the main mechanisms found. Including details regarding these mechanisms will help substantiate trait choice and broaden the discussion about future conservation strategies of assessed species.

\section{Material and Methods}

We searched the literature for studies that evaluated variation in the four traits mentioned earlier in response to recent climate change regarding organisms from any taxa within any level (population, community, and ecosystem). We chose these four traits because they are commonly used in CCVAs (Gardali et al. 2012; Reside et al. 2016; Borges et al. 2019) and are more widely available in the literature. As the study's objective was to present a broad discussion for each trait, more traits would excessively increase the number of pages in the study. The search was carried out in July 2019 in the Thomson Reuters ISI Web of Science online database. It included articles published between 1945 and 2019, using the following search terms: ("trait" OR "clutch size" OR "diet" OR “dispersion" OR "climatic tolerance" OR "thermic tolerance" OR "heat tolerance") AND ("climate change" OR "global warming" OR "temperature increase").

We excluded studies that: (1) belonged to Web of Science categories not related to ecology (e.g. agronomy, veterinary medicine, tropical medicine), (2) did not relate (directly or indirectly) possible trait changes to climate change, and (3) did not present any explanation (through empirical data) to the mechanisms involved in the observed responses (e.g. changes in distribution areas, phenology and abundance). Studies cited by the articles obtained in our search were also included in our synthetic review if they fulfilled the requirements. The search 
generated a total of 1164 articles. After the exclusions following the criteria mentioned above, 197 articles were evaluated.

\section{Results and Discussion}

\section{Clutch size}

Clutch size is one of the best-studied life-history traits in birds, and its variation throughout the latitude gradient is well known, with larger clutch size in higher latitudes (Lack 1947; Skutch 1949; Ashmole 1963; Ricklefs 1980; Evans et al. 2005; Jetz et al. 2008). As expected, studies that assess clutch size are focused on birds and have been carried out mainly in the temperate region (Table 1). Birds that inhabit temperate and tropical areas adopt different life-history strategies to respond to climate change through other mechanisms (Table 1).

Clutch size is related to species fecundity; thus, it indicates the population ability to recruit. Species with smaller clutch size present low reproductive potential and consequently a slower response to risk factors, which would make them more vulnerable to decline and extinction (Smith and Quin 1996; Pimm 1991; Hero et al. 2005). On the other hand, species with larger clutch size may present a higher ability to respond to climate change, for they present shorter life cycles (Mckinney 1997). Larger clutch size is related to the probability of occupying broader geographic areas, higher dispersal ability and higher ability to colonise changing habitats and explore new opportunities (Duncan et al. 2001; Hero et al. 2005).

Some studies have found a significant relationship between clutch size and environmental variables. In temperate regions (with severe winter), studies with birds have shown that temperature increases have led to larger clutch sizes (Jarvinen 1996; Przybylo et al. 2000; Møller 2002; Husek and Adamík 2008; Table 1). The mechanism involved in this physiological adjustment seems to be related to resource availability. In these regions, the cold climate imposes food shortage (Jarvinen
1986, 1996), and higher temperatures lead to higher food availability, allowing species to have a higher number of broods. Annual variation in temperature, which reflects the seasonality of resources, was the most crucial variable to explain clutch size in a global assessment (Jetz et al. 2008). For example, the clutch size of owls in Finland is strongly determined by the abundance of their prey (voles): warmer years, with thinner snow cover, favour a higher abundance of voles, allowing larger clutch size (Lehikoinen et al. 2011). Such a positive relationship between food availability and mean clutch size in birds is well-known (Lack 1947; Price 1985; Gibbs and Grant 1987). Correlation between clutch size and climatic variables was also confirmed for other groups such as lizards (Smith et al. 1995; Abell 1999) and butterflies (Karlsson and Wiklund 2005; Saastamoinen 2007). In this sense, for species that live in temperate regions, where the cold is a limiting factor for population regulation, climate change may positively impact environmental conditions, increase resource availability, and allow larger clutch size.

In the tropical region, resource seasonality is less intense, and the reproductive season is longer, which allow species to attempt reproduction more frequently per season (Martin, 1996). A higher number of attempts to reproduce may lead to smaller clutch size, as the parents need to save energy to invest in the next clutch (Slagsvold 1984; Farnsworth and Simons 2001). This seems to be a good strategy in the tropics since nest predation is higher than in the temperate region, which would allow the spread of predation risk in numerous reproduction attempts (Cody 1966; Kulesza 1990; Martin 1995; Griebeler et al. 2010; Table1). If clutch size depends on nest predation rate, as proposed by Skutch (1949), if larger broods attract more predators, natural selection will favour smaller clutch sizes in the tropics (Martin et al. 2000). Considering that, a possible consequence of climate change to species that inhabit the tropics is that temperature increase and rainfall decrease might shorten the reproductive season, leading to a reduction in the number of reproduction attempts, which could force species to compensate by increasing clutch size (Lovette and Fitzpatrick 2016).

Table 1. Possible mechanisms that explain how clutch size may influence species responses to climate change and their respective studies.

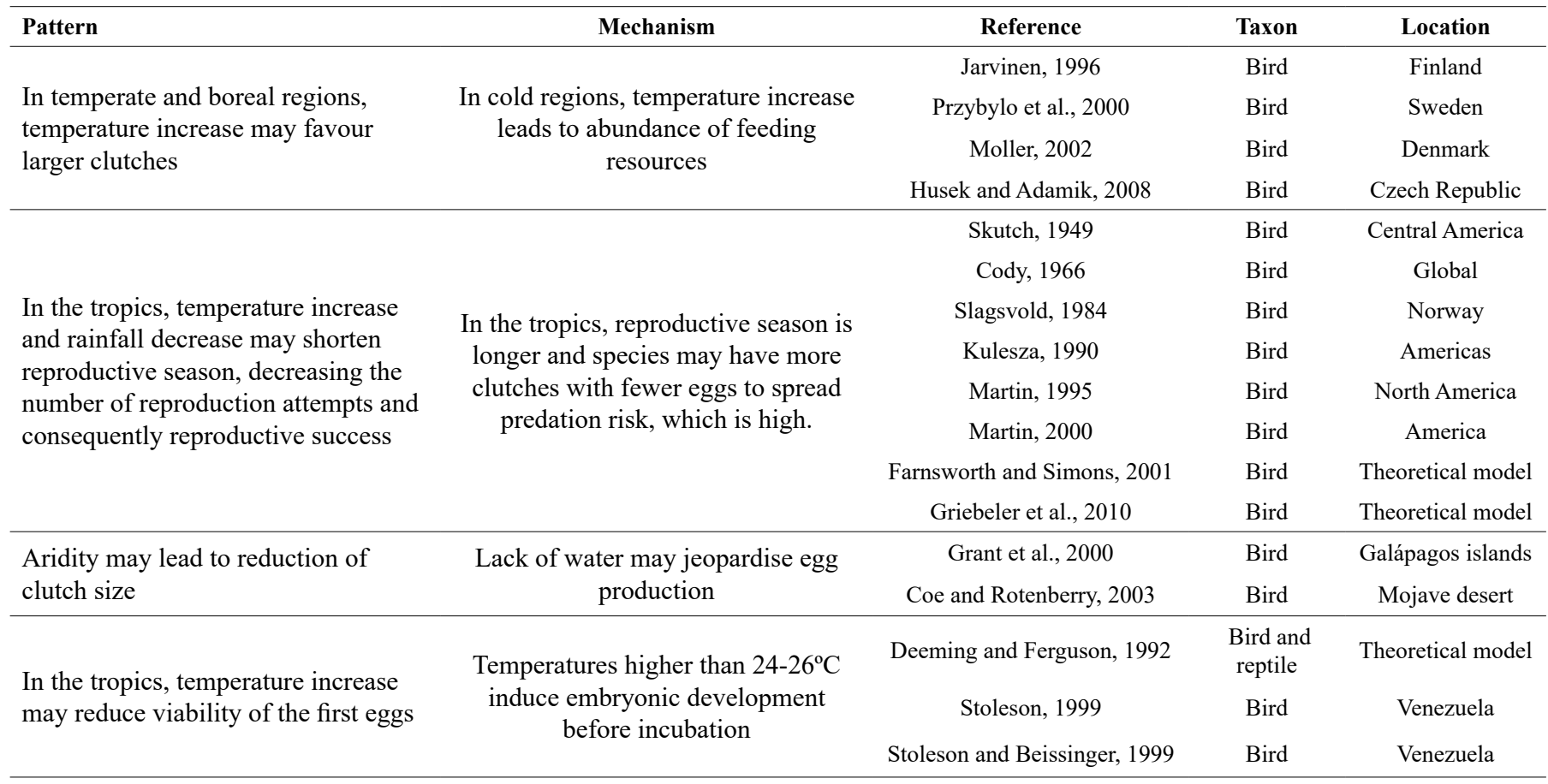


That would represent a risk for species since the tropics nest predation rate is relatively high, reaching $80-90 \%$ (revised by Stutchbury and Morton 2001).

In regions where climate change will cause temperature increase and significant rainfall decrease, making the areas arider, species tend to reduce the clutch size (Grant et al. 2000; Coe and Rotenberry 2003; Table 1). A study in the California desert has shown that, in territories that received water supplementation (treatment), a desert sparrow had a significantly larger clutch size than in non-supplemented territories (control) (Coe and Rotenberry 2003). This result shows that environment variables have an indirect effect (regulating food availability) and act directly on physiology, so that supplemented females can allocate more water to egg production. During the reproductive period, females need a significantly higher amount of water to produce eggs since they contain a high percentage of water (Bartholomew and Cade 1963; Reynolds and Waldron 1999).

Another hypothesis used to explain smaller clutch size in the tropical region than the temperate region is the egg-viability hypothesis (Stoleson and Beissinger 1999; Table 1). According to this hypothesis, in the tropics, where the temperature is higher, extended exposure of the eggs to temperatures higher than $24-26^{\circ} \mathrm{C}$ (physiological zero) may trigger embryonic development even when the eggs are not incubated. Such premature development of the embryos below optimum incubation temperature $\left(36-38^{\circ} \mathrm{C}\right)$ results in abnormal growth of some tissues and consequent embryo death (Deeming and Ferguson 1992; Stoleson 1999). Therefore, birds that live in the tropics may lay smaller clutches to start active incubation earlier to keep the viability of the first eggs instead of waiting until many eggs are laid (Stoleson and Beissinger 1999). Based on this hypothesis, in a scenario of temperature increase, it is expected that species initiate incubation earlier and earlier to avoid loss of the first eggs, which can lead to smaller clutch size, since premature incubation or contact with the eggs may interrupt follicular growth and egg-laying (Haywood 1993).
Available evidence shows that species can adjust to climate change through phenotypic plasticity instead of altering their genetic constitution through microevolutionary adaptation (Gienapp et al. 2008). There seems to be low, or no additive genetic variation to clutch size and most intrapopulation variation is due to transitory environmental effects (Gibbs 1988). Species may present fast physiologic responses adjusting the clutch size to environmental changes (Gibbs 1988; Baker 1995; Coe and Rotenberry 2003). For example, the mean clutch size for sparrows in New York was 4.7 eggs, while in Costa Rica, it was two eggs (reviews in Baker 1995). When sparrows captured in Costa Rica were raised in aviaries in New York, their clutch size was $3.50(+0.46)$ eggs in the first year and $4.62(+0.55)$ in the second year. Sparrows from New York raised in nearby aviaries under the same feeding conditions, and same pressures had a mean clutch size of $4.89(+0.48)$ eggs (Baker 1995). This example shows that species do not need several generations to adjust their clutch size to climatic conditions. Therefore, negative impacts on species that will be forced to reduce their clutch size, such as low population recruitment, could occur at a somewhat accelerated pace, thus increasing their vulnerability.

\section{Diet breadth}

In general, studies that assess climatic effects on diet are not focused on a specific taxon, but there is a prevalence of studies with vertebrates living in the temperate region (Table 2). Diet is an important trait that summarises distinct morphological, physiological and behavioural characteristics of a given organism, determining how it interacts with the biotic and abiotic environments (Donnell et al. 2012; Abrahamczyk and Kessler 2014). It is expected that species with specialised diets present narrow niches, low local abundance and restricted geographic distribution (Mckinney 1997). On the other hand, generalist species have flexible behaviour and can change their feeding habits to adapt to changes in resource availability (O’Donoghue et al. 1998). Therefore, the diet breadth of a given species may influence its extinction risk

Table 2. Possible mechanisms that explain how diet may influence species responses to climate change and their respective studies.

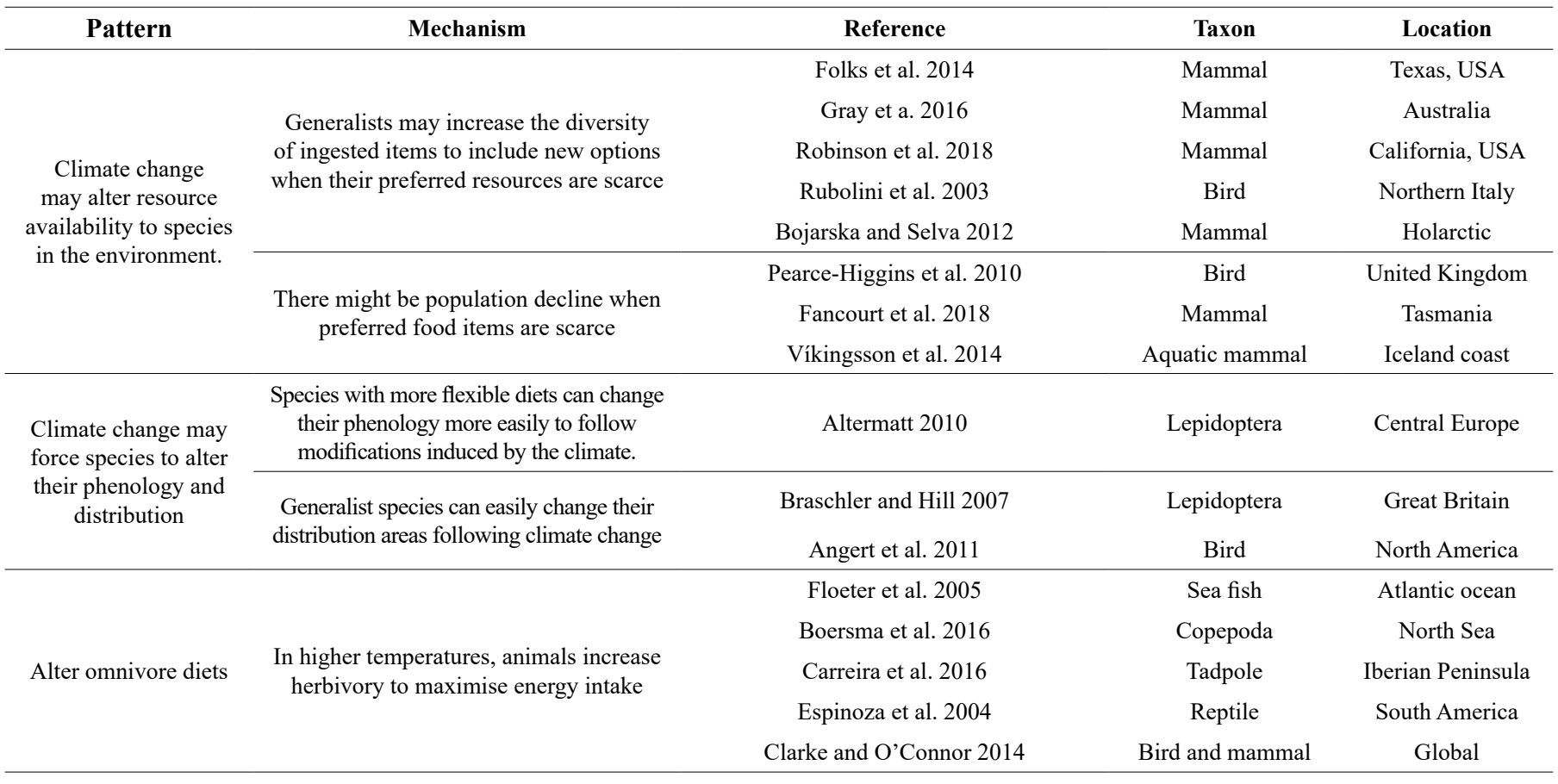


(Boyles and Storm 2007). Species with a more specialised diet are associated with higher probabilities of negative response to climate change (Pacifici et al. 2017). We will discuss three main mechanisms species may respond to climate change through their diets (Table 2).

Climate change may affect the availability of feeding resources. In regions where these resources will decrease, species with specialised diets will become more sensitive, presenting a higher extinction risk than generalist species (Chessman 2013). Species with broader diet breadth can avoid hunger by changing their diet to the available food item during adverse climatic conditions (Brändle et al. 2002). Such plasticity in the diet is a mechanism that has allowed species to deal with climate-related fluctuations in availability and abundance of resources (Furness 1996; Ancona et al. 2012). Generalist species can increase diet diversity in response to unfavourable changes in the weather when their preferred resources are scarce. They are led to supplement their diets with available resources at the moment (Folks et al. 2014; Gray et al. 2016; Table 2). For example, temperature increase in North Pacific waters alters the availability of sea lion preys, making them change their diet, increasing the diversity of consumed preys (Robinson et al. 2018). In Northern Italy, owls have become more generalist under adverse climatic conditions: increased rainfall and decreased temperature increased the breadth of owls' diets. (Rubolini et al. 2003). Alternatively, species with specialised diets may not respond to resource fluctuation and therefore experience higher extinction risk. For mountain birds, temperature increase can result in population decrease caused by the abundance of preys, insects from the Tipulidae family adapted to cold weather (PearceHiggins 2010). Temperature and rainfall increase during winter caused a significant decrease in the Eastern quoll population due to a reduction in the abundance of moth larvae (Fancourt et al. 2018).

Diet type may influence species ability to change their phenologic events (Altermatt 2010) and their distribution area (Angert et al. 2011) to follow climate change. Species that are not able to change their distribution areas fast enough to follow their adequate climatic conditions are at higher risk of extinction (Devictor et al. 2008), as well as those species that cannot change phenology to match species that they depend on for survival (Visser and Both 2005). Generally, diet generalists are expected to be more likely to find adequate resources in new areas. They should, therefore, present a greater ability to change their distributions than specialists, which could be more limited by the phenology of species they depend on (Angert et al. 2011; Buckley and Kingsolver 2012). Broader diets can facilitate the expansion of distribution areas driven by climate (Braschler and Hill 2007) and the establishment and persistence of species in new environments (Estrada et al. 2016). However, a specialist may have a greater probability of following spatial changes if its host species or prey also changes (Betzholtz et al. 2013; Auer and King 2014). Generally, diet specialists could be more affected by climate change since they present narrower distribution, are less likely to leave their habitats (Caldas 2014) and alter their phenologic events (Altermatt 2010) to track adequate climatic conditions.

The temperature increase may cause omnivore species to change their diet, becoming more herbivores and fewer carnivores (Table 2). For ectotherms, low body temperature makes herbivory energetically unfavourable, as it constrains the rate at which energy can be extracted from the diet (Floeter et al. 2005; Boersma et al. 2016). For marine herbivorous fishes, herbivory is only possible above a threshold of $15^{\circ} \mathrm{C}$
(Floeter et al. 2005). There seems to be a consensus that due to better digestion of vegetal material at high temperatures, ectotherms might maximise energy intake and maintain high metabolic rates in higher temperatures by increasing herbivory (Carreira et al. 2016). This idea is supported by studies that have found that herbivory increases in response to higher temperatures in several groups, such as Copepoda (Boersma et al. 2016), fish (Floeter et al. 2005), tadpoles (Carreira et al. 2016) and reptiles (Espinoza et al. 2004). Even amongst endotherms, herbivores maintain higher body temperature than carnivores (Clarke and O'Connor 2014). Although omnivores can regulate their diet to deal with temperature increase caused by climate change, changing to a more herbivore diet and its adaptive value is variable among species (Carreira et al. 2016). Besides, an increase in herbivory in response to global warming can alter food chains, species interactions, and ecosystems' functioning.

\section{Dispersal ability}

Birds and lepidopterans are the best-represented taxa in studies regarding climatic effects on dispersal ability, and no studies were carried out in the tropical region (Table 3). Understanding species ability to respond to climate change is a fundamental point to identify species that experience higher risk (Møller et al. 2008; Hurlbert and Liang 2012). Species that cannot change their annual cycles and their distributions to follow their suitable climatic conditions will be prone to higher extinction risk (Møller et al. 2008; Corlett and Westcott 2013). In this sense, dispersal ability is a crucial attribute for species. It is expected that those with higher dispersal ability respond more quickly to climate change, presenting lower extinction risk (Pöyry et al. 2009; Angert et al. 2011).

Climate change can affect the dispersal processes of organisms both directly and indirectly (Travis et al. 2013; Table 3). Indirect mechanisms (e.g. altering resource availability and climatic suitability of the habitat) may lead species to change their distribution areas. Their annual cycles will be discussed in the following paragraphs (Table 3). On the other hand, climate change may directly interfere with behaviour, affecting the organisms' decisions to stimulate or inhibit dispersal (Table 3). Higher temperatures increase the dispersal of moths (Battisti et al. 2006), butterflies (Cormont et al. 2011) and birds (Møller et al. 2006) and decrease dispersal of lizards (Massot et al. 2008). Flooding increases the dispersal of an aquatic bird in Canada (Roche et al. 2012), and the reduction of snow cover decreases the dispersal of wolverines in the USA (Schwartz et al. 2009). These examples indicate that climatic variables may increase or reduce dispersal depending on the system and the species (Travis et al. 2013). Moreover, species response may depend on weather and landscape configuration (Delattre et al. 2013). In more fragmented landscapes, dispersal distance is longer at lower temperatures, while in continuous landscapes, dispersal distance is longer at higher temperatures.

Recent climate change is quickly altering the location of areas with a suitable climate for certain species (Loarie et al. 2009). To survive, species must move fast enough to follow such changes (Chen et al. 2011; Lenoir and Svenning 2015). Therefore, as expected for the future, climate change might be a significant threat to species persistence since rates of distribution changes should be much higher than those observed in the past (Williams and Blois 2018). Some studies show that many organisms will not be able to disperse fast enough to follow their climatic 
Borges, F.J.A. et al.

Table 3. Effects and possible mechanisms that explain how dispersal influences species responses to climate change and their respective studies.

\begin{tabular}{|c|c|c|c|c|c|}
\hline Effect & Pattern & Mechanism & Reference & Taxon & Location \\
\hline \multirow{7}{*}{ Direct } & \multirow{7}{*}{$\begin{array}{l}\text { Affecting decision } \\
\text { to disperse }\end{array}$} & \multirow{5}{*}{$\begin{array}{l}\text { Increasing/ stimuating } \\
\text { dispersion }\end{array}$} & Battisti et al. 2006 & Moth & Europe \\
\hline & & & Cormont et al. 2011 & Butterfly & Netherlands \\
\hline & & & Møller et al. 2006 & Bird & Denmark \\
\hline & & & Pärn et al. 2012 & Bird & Norway \\
\hline & & & Delattre et al. 2013 & Butterfly & France \\
\hline & & \multirow{2}{*}{$\begin{array}{l}\text { Decreasing/ inhibiting } \\
\text { dispersion }\end{array}$} & Massot et al. 2008 & Lizzard & France \\
\hline & & & Bullock et al. 2012 & Plant & Great Britain \\
\hline \multirow{12}{*}{ Indirect } & \multirow{4}{*}{$\begin{array}{l}\text { Changing the } \\
\text { distribution area }\end{array}$} & \multirow{4}{*}{$\begin{array}{l}\text { Higher dispersal ability, } \\
\text { higher probability } \\
\text { of tracking suitable } \\
\text { environmental conditions }\end{array}$} & Pöyry et al. 2009 & Butterfly & Finland \\
\hline & & & Angert et al. 2011 & Plant & Switzerland \\
\hline & & & Hill et al. 2002 & Butterfly & Great Britain \\
\hline & & & Williams and Blois 2018 & Mammal & North America \\
\hline & \multirow{8}{*}{$\begin{array}{l}\text { Changing } \\
\text { phenological } \\
\text { responses }\end{array}$} & \multirow{8}{*}{$\begin{array}{l}\text { Short-distance migrants } \\
\text { respond more quickly to } \\
\text { climate change than long- } \\
\text { distance migrants. }\end{array}$} & Butler 2003 & Bird & North America \\
\hline & & & Swanson and Palmer 2009 & Bird & USA \\
\hline & & & Tryjanowski et al. 2002 & Bird & Poland \\
\hline & & & Tøttrup et al. 2010 & Bird & Europe \\
\hline & & & Hurlbert and Liang 2012 & Bird & North America \\
\hline & & & Rubolini et al. 2010 & Bird & Germany \\
\hline & & & Végvári et al. 2010 & Bird & Europe \\
\hline & & & Rubolini et al. 2007 & Bird & Europe \\
\hline
\end{tabular}

niches, even highly mobile species (Pearson 2006; Devictor et al. 2008, 2012; Schloss et al. 2012). Species with low dispersal ability might lose significant parts of their distribution areas in the future (Krause et al. 2015), hence facing higher extinction risk (Pearson 2006; Corlett and Westcott 2013). Therefore, dispersal ability is a good predictor of species vulnerability to climate change. Both empirical observations (Warren et al. 2001; Hill et al. 2002; Pöyry et al. 2009; Angert et al. 2011) and model projections (Krause et al. 2015; Methorst et al. 2017; Williams and Blois 2018) evidence that higher dispersal ability indicates higher ability to change distribution to follow climate displacement (Table 3).

Recent global warming has already caused significant changes in many species' life cycles (Walther et al. 2002; Parmesan and Yohe 2003). Generally, plants and animals have advanced their phenologies in response to temperature increase (Parmesan and Yohe 2003; Parmesan 2006). However, consumers and predators at higher trophic levels in the food chain might not respond in the same proportion, leading to a mismatch between reproductive period and resource availability (Visser et al. 1998, 2004; Visser and Both 2005). Species that cannot advance their arrival to reproduction sites to match the peak of food abundance may suffer population declines and, consequently, be more prone to extinction (Both et al. 2006; Møller et al. 2008).

Migratory birds should advance the beginning of the migration to follow the phenology of plants and invertebrates in their reproduction areas (Sparks et al. 2005). Indeed, as a response to temperature increase in the last years, migratory birds have arrived earlier in their reproduction sites (Butler 2003; Hurlbert and Liang 2012). However, literature shows that long-distance migrants cannot respond to climatic change as quickly as short-distance migrants do and arrive later (Table 3). This happens because long-distance migrants experience slower temperature increase in wintering areas than their reproduction areas, while short-distance migrants are exposed to warm weather throughout the year (Lehikoinen et al. 2004). Therefore, short-distance migrants have more and better cues to match their phenology with resource phenology (Jones and Cresswell 2010). Thus, long-distance migratory behaviour can represent an essential constraint to responses to climate change, contributing to the decline of some species (Berthold et al. 1998; Møller et al. 2008; Jones and Cresswell 2010; Rubolini et al. 2010).

\section{Climatic tolerance}

Studies assessing species climatic tolerance are focused on ectotherms, and most of them were carried out on a global scale (Table 4). Tolerance to climatic conditions is one of the most critical factors determining how species are distributed around the globe (Thomas 2010). A variation in climatic tolerance among species is an important characteristic to determine their responses to climate change, as it can alter distribution and survival (Deutsch et al. 2008; Huey et al. 2012; Caldwell et al. 2015; Rugiu et al. 2018). Species with higher thermic tolerance occupy broader geographic areas (Bozinovic et al. 
2011) and will deal better with global warming (Calosi et al. 2008; Buckley et al. 2012; Huey et al. 2012). In general, the thermic tolerance of an organism is proportional to the magnitude of temperature variation experienced in its habitat, steeply increasing with latitude (Deutsch et al. 2008). Thus, species from the tropics, which inhabit environments with lower temperature variation throughout the year, have narrower thermic tolerance than species from temperate regions (Deutsch et al. 2008; Huey et al. 2009, 2012; Duarte et al. 2012; Khaliq et al. 2014; Table 4). Deutsch et al. (2008) have reported that heat tolerance in tropical insects is, on average, only one-fifth of the tolerance of insect species from temperate regions. Besides that, tropical species already live in warmer environments, close to their critical temperature, compared to species from the temperate areas, which live in colder environments, far from their critical temperature (Sunday et al. 2012; Araújo et al. 2013; Khaliq et al. 2014). Therefore, even slight temperature increases might be a threat to tropical species.

Heat tolerance is more conserved amongst lineages than cold tolerance, implying that many species might have lost their evolutionary potential to respond to global warming (Addo-Bediako et al. 2000; Huey et al. 2009; Araújo et al. 2013). When organisms are exposed to temperatures close to their upper thermal limit, biological activity suffers from several limitations and might compromise survival (Somero 2011). Furthermore, it is unlikely that species can persist under conditions that surpass their physiological tolerance limits (Calosi et al. 2010). Thus, climatic conditions expected in the future might negatively affect population abundance and potentially compromise their persistence (Rugiu et al. 2018). However, while tropical species might be severely affected, species from temperate regions might benefit from temperature increase, responding with higher population growth rates and aptitude (Deutsch et al. 2008; Caldwell et al. 2015; Carrascal et al. 2016; Table 4).
Such pattern of greater physiological vulnerability to climatic changes in tropical species, when compared to species from temperate areas, has been shown to ectotherms, especially reptiles (Deutsch et al. 2008; Tewksbury et al. 2008; Huey et al. 2009, 2010; Diamond et al. 2012; Duarte et al. 2012; Sunday et al. 2012; Hoffmann et al. 2013; Caldwell et al. 2015). For endotherms, on the other hand, the relationship between higher thermic tolerance in species that experience higher climatic variability was observed in birds but not in mammals (Khaliq et al. 2014). Even though most ectotherms, particularly those from the temperate region, might tolerate projected temperature increases across significant ranges of their distributions, potential vulnerability to projected temperatures increases from polar regions to tropical areas (Khaliq et al. 2014). Unlike the observed pattern for ectotherms (Addo-Bediako et al. 2000; Deutsch et al. 2008), endotherms present low phylogenetic conservatism regarding climatic tolerance to respond to temperature increase through physiological adaptation (Khaliq et al. 2015). In temperate regions, endotherms distribution is limited by extremes of low temperature via physiological cold tolerance of species (Khaliq et al. 2017). Global warming scenarios might benefit species living in those regions, increasing their abundance (Carrascal et al. 2016). In the tropics, endotherms (especially mammals) seem limited by other factors, such as biotic interactions, rather than climatic conditions (Khaliq et al. 2017).

Overall, species that present the lowest climatic tolerances will be more affected by climate change. Species from the tropical region and mainly ectotherms will be more vulnerable to projected temperature increases in the future (Table 4). Endotherms can keep high and constant body temperature, which is generally independent of ambient climatic conditions (MacNab 2012). On the other hand, ectotherms might be more vulnerable as their physiology, locomotion, growth and

Table 4. Possible mechanisms that explain how climatic tolerance may influence species responses to climate change and their respective studies.

\begin{tabular}{|c|c|c|c|c|}
\hline Pattern & Mechanisms & Reference & Taxon & Location \\
\hline \multirow{9}{*}{$\begin{array}{l}\text { Species from tropical regions } \\
\text { are more vulnerable to climatic } \\
\text { change than species from } \\
\text { temperate regions }\end{array}$} & \multirow{9}{*}{$\begin{array}{l}\text { Species from tropical regions } \\
\text { have narrower thermic tolerance } \\
\text { and live in environments where } \\
\text { the temperature is close to their } \\
\text { upper thermal limit }\end{array}$} & Deutsch et al. 2008 & Ectotherms & Global \\
\hline & & Tewksbury et al. 2008 & Lizard & Global \\
\hline & & Huey et al. 2009 & Lizard & Neotropics \\
\hline & & Sunday et al. 2012 & Ectotherms & Global \\
\hline & & Huey et al. 2012 & Ectotherms and endotherms & Global \\
\hline & & Diamond et al. 2012 & Ant & Global \\
\hline & & Hoffmann et al. 2013 & Ectotherms & Global \\
\hline & & Khaliq et al. 2014 & Bird and mammal & Global \\
\hline & & Caldwell et al. 2015 & Lizard & Tasmania \\
\hline \multirow{6}{*}{$\begin{array}{l}\text { Species from temperate regions } \\
\text { are less vulnerable and may } \\
\text { benefit from climate change }\end{array}$} & \multirow{6}{*}{$\begin{array}{c}\text { Species present broader thermic } \\
\text { tolerance and live in environments } \\
\text { where the temperature is far from } \\
\text { their upper limits }\end{array}$} & Deutsch et al. 2008 & Ectotherms & Global \\
\hline & & Sunday et al. 2012 & Ectotherms & Global \\
\hline & & Huey et al. 2012 & Ectotherms and endotherms & Global \\
\hline & & Khaliq et al. 2014 & Bird and mammal & Global \\
\hline & & Caldwell et al. 2015 & Lizard & Tasmania \\
\hline & & Carrascal et al. 2016 & Bird & Spain \\
\hline \multirow{5}{*}{$\begin{array}{l}\text { Ectotherms are more vulnerable } \\
\text { to climate change than } \\
\text { endotherms }\end{array}$} & \multirow{5}{*}{$\begin{array}{l}\text { Ectotherms present higher niche } \\
\text { conservatism and lower capacity } \\
\text { to adjust their physiology }\end{array}$} & Addo-Bediako et al. 2000 & Insect & Global \\
\hline & & Deutsch et al. 2008 & Ectotherms & Global \\
\hline & & Sinervo et al. 2010 & Lizard & Mexico \\
\hline & & Khaliq et al. 2015 & Bird and mammal & Global \\
\hline & & Khaliq et al. 2017 & Bird and mammal & Global \\
\hline
\end{tabular}


Borges, F.J.A. et al

reproduction are strongly influenced by ambient temperature (Deutsch et al. 2008). Moreover, warmer temperatures may force ectotherms to spend more time in shelters to avoid lethally high temperatures, restricting the time available for other vital activities such as foraging, territory defence and mating (Sinervo et al. 2010). Due to their low ability to respond to climate change, several ectotherm populations were locally extinct in recent decades, and temperature increase might lead to the extinction of almost $40 \%$ of lizard populations and $20 \%$ of lizard species globally 2080 (Sinervo et al. 2010).

\section{Conclusions}

Overall, the literature review performed regarding the four chosen traits enabled us to present and discuss mechanisms that might explain species responses to climate change. As shown here, response to climate change is highly variable among species and regions. Some species may exhibit a critical response to a specific climate variable. In contrast, others may have a minimal response, and some might even present a contradictory response from what is expected, depending on the region they inhabit. Explaining such variation has become a significant challenge to conservationists in this century. Such explanation would allow the identification of species at higher extinction risk, the definition of the best conservation strategies, and the resources' strategic direction. It was also possible to verify bias concerning region and taxa in the evaluated studies. The tropical region, which holds more sensitive species, was weakly represented, while most studies have focused on the temperate region. For some traits, studies concentrate on a specific group and neglect others; for example, most studies assessing climatic tolerance have concentrated on reptiles.

Species exposed to a higher magnitude of climate warming should present more pronounced biological responses (Chen et al. 2011). However, intrinsic differences between species' life-history traits, physiology and other ecological characteristics are fundamental to determine their vulnerability (Williams et al. 2008; Foden et al. 2013). Assessments of climate change vulnerability that consider both exposure and traits that define sensitivity and adaptive ability could be helpful tools (Foden et al. 2013; Böhm et al. 2016). However, trait choice should be based on empirical evidence that shows the relevance of such traits in determining the vulnerability of assessed species.

This review shows that the four evaluated traits are significant predictors of species responses to climate change, and we present the main mechanisms involved in each response. Therefore, clutch size, diet breadth, dispersal ability and climatic tolerance are essential traits for vulnerability assessments. Even though some evidence might lead us to conclude that species with smaller clutch size, with specialised diets, low dispersal ability and lower climatic tolerance would experience higher risk due to climate change, the set of studies evaluated here indicates that the risk depends on the region and the species group considered. While species from the temperate region could benefit from temperature increase with greater resource availability, increasing clutch size and expanding the distribution area through dispersal, species from the tropics could be severely affected. They have lower climatic tolerance and already live close to their limits of heat tolerance. Vulnerability is higher for ectotherms because, unlike endotherms, they cannot control body temperature and their biological activities depend on the climatic conditions of the environment. Ectotherms from the tropical region will not escape from temperature increase through dispersal (Buckley et al. 2013).

The lack of response in a trait may interfere with the response of another feature. In the temperate region, temperature increase causes advanced flowering in plants and an abundance of insects. Thus, birds that spend the winter in other areas should advance their arrival so that the reproductive period matches food availability. Species that cannot advance their arrival might face food scarcity during reproduction, leading to smaller clutch size. In the tropics, species present lower thermic tolerance, affecting their dispersal ability to follow suitable climatic conditions if they have to cross warmer areas.

As we understand the mechanisms involved in the response of other traits, we will enhance our ability to predict climate change impacts, enabling conservation practices that are more adequate to protect species. The increase of this type of studies could facilitate understanding which characteristics are more informative to each species group within each region. Besides that, understanding the mechanisms through which traits influence species responses to climatic changes may help justify the traits included in vulnerability assessments, improving their results and making them more useful. For that, CCVAs need to be more integrated with the ecology literature to assess how species traits respond to changes in the climate.

\section{Acknowledgements}

$\mathrm{RL}$ research is funded by CNPq (grant \#306694/2018-2). FJAB received a $\mathrm{PhD}$ scholarship from $\mathrm{CNPq}$. This paper contributes to the INCT in Ecology, Evolution and Biodiversity Conservation founded by MCTIC/CNPq (grant \#465610/2014-5) and FAPEG (grant \#201810267000023). This work was supported by Brazilian Council for Scientific and Technological Development (CNPq).

\section{Author Contributions}

Fábio Júlio Alves Borges: Originally formulated the idea, performed the literature search, data analysis and wrote the first version of the manuscript.

Rafael Loyola: Commented and revised the manuscript, substantially improving the final version.

\section{Conflict of Interest}

The authors declare that they have no conflict of interest.

\section{References}

Abell AJ (1999) Variation in Clutch Size and Offspring Size Relative to Environmental Conditions in the Lizard Sceloporus virgatus. Journal of Herpetology 33:173-180

Abrahamczyk S, Kessler M (2014) Morphological and behavioural adaptations to feed on nectar : how feeding ecology determines the diversity and composition of hummingbird assemblages. Journal of Ornithology 156:333-347. doi: 10.1007/s10336-014-1146-5

Addo-Bediako A, Chown SL, Gaston KJ (2000) Thermal tolerance, climatic variability and latitude. Proceedings of the Royal Society B: Biological Sciences 267:739-745

Altermatt F (2010) Tell me what you eat and I'll tell you when you fly: Diet can predict phenological changes in response to climate change. Ecology Letters 13:1475-1484. doi: 10.1111/j.1461- 0248.2010.01534.x 
Ancona S, Calixto-Albarrán I, Drummond H (2012) Effect of El Niño on the diet of a specialist seabird, Sula nebouxii, in the warm eastern tropical Pacific. Marine Ecology Progress Series 462:261-271. doi: 10.3354/meps09851

Angert AL, Crozier LG, Rissler LJ, et al (2011) Do species' traits predict recent shifts at expanding range edges? Ecology Letters 14:677-689. doi: 10.1111/j.1461-0248.2011.01620.x

Araújo MB, Ferri-Yáñez F, Bozinovic F, et al (2013) Heat freezes niche evolution. Ecology Letters 16:1206-1219. doi: 10.1111/ele.12155

Ashmole NP (1963) The regulation of numbers of tropical oceanic birds. Ibis 103b:458-473

Auer SK, King DI (2014) Ecological and life-history traits explain recent boundary shifts in elevation and latitude of western North American songbirds. Global Ecology and Biogeography 23:867-875. doi: 10.1111/ geb.12174

Baker M (1995) Environmental Component of Latitudinal Clutch-Size Variation in House Sparrows (Passer domesticus). The Auk 112:249-252

Bartholomew GA, Cade TJ (1963) The Water Economy of Land Birds. The American Naturalist 80:504- 539

Battisti A, Stastny M, Buffo E, Larsson S (2006) A rapid altitudinal range expansion in the pine processionary moth produced by the 2003 climatic anomaly. Global Change Biology 12:662-671. doi: 10.1111/j.13652486.2006.01124.x

Berthold P, Fiedler W, Schlenker R, Querner U (1998) 25Year Study of the Population Development of Central European Songbirds: A General Decline, Most Evident in Long-Distance Migrants. Naturwissenschaften 85:350-353. doi: $10.1007 / \mathrm{s} 001140050514$

Betzholtz PE, Pettersson LB, Ryrholm N, Franzén M (2013) With that diet, you will go far: Trait-based analysis reveals a link between rapid range expansion and a nitrogen-favoured diet. Proceedings of the Royal Society B: Biological Sciences 280:. doi: 10.1098/rspb.2012.2305

Boersma M, Mathew KA, Niehoff B, et al (2016) Temperature driven changes in the diet preference of omnivorous copepods: no more meat when it's hot? Ecology Letters 19:45-53. doi: 10.1111/ele.12541

Böhm M, Cook D, Ma H, et al (2016) Hot and bothered: Using trait-based approaches to assess climate change vulnerability in reptiles. Biological Conservation 204:32-41. doi: 10.1016/j.biocon.2016.06.002

Bojarska K, Selva N (2012) Spatial patterns in brown bear Ursus arctos diet: the role of geographical and environmental factors. Mammal Review 42:120-143. doi: 10.1111/j.1365-2907.2011.00192.x

Borges FJA, Ribeiro BR, Lopes LE, Loyola R (2019) Bird vulnerability to climate and land use changes in the Brazilian Cerrado. Biological Conservation 236:347-355. doi: 10.1016/j.biocon.2019.05.055

Both C, Bouwhuis S, Lessells CM, Visser ME (2006) Climate change and population declines in a long-distance migratory bird. Nature 441:81-83. doi: 10.1038 /nature04539

Boyles JG, Storm JJ (2007) The Perils of Picky Eating: Dietary Breadth Is Related to Extinction Risk in Insectivorous Bats. PLoS ONE 2:e672. doi: 10.1371/journal.pone.0000672

Bozinovic F, Calosi P, Spicer JI (2011) Physiological Correlates of Geographic Range in Animals. Annual Review of Ecology, Evolution and Systematics 42:155-179. doi: 10.1146/annurev-ecolsys-102710-145055

Brändle M, Prinzing A, Pfeifer R, Brandl R (2002) Dietary niche breadth for Central European birds: correlations with species-specific traits. Evolutionary Ecology Research 4:643-657

Braschler B, Hill JK (2007) Role of larval host plants in the climate-driven range expansion of the butterfly Polygonia c-album. Journal of Animal Ecology 76:415-423. doi: 10.1111/j.1365-2656.2007.01217.x

Buckley LB, Hurlbert AH, Jetz W (2012) Broad-scale ecological implications of ectothermy and endothermy in changing. Global Ecology and Biogeography 21:873-885. doi: 10.1111/j.1466-8238.2011.00737.x

Buckley LB, Kingsolver JG (2012) Functional and Phylogenetic Approaches to Forecasting Species' Responses to Climate Change. Annual Review of Ecology, Evolution, and Systematics 205-226. doi: 10.1146/annurevecolsys-110411-160516
Buckley LB, Tewksbury JJ, Deutsch CA (2013) Can terrestrial ectotherms escape the heat of climate change by moving? Proceedings of the Royal Society B: Biological Sciences 280:20131149. doi: 10.1098/rspb.2013.1149

Bullock JM, White SM, Prudhomme C, et al (2012) Modelling spread of British wind-dispersed plants under future wind speeds in a changing climate. Journal of Ecology 100:104-115. doi:10.1111/j.1365 2745.2011.01910.x

Butler CJ (2003) The disproportionate effect of global warming on the arrival dates of short-distance migratory birds in North America. Ibis 145:484-495

Caldas A (2014) Species Traits of Relevance for Climate Vulnerability and the Prediction of Phenological Responses to Climate Change. Journal of the Lepidopterists' Society 68:197-202

Caldwell AJ, While GM, Beeton NJ, Wapstra E (2015) Potential for thermal tolerance to mediate climate change effects on three members of a cool temperate lizard genus, Niveoscincus. Journal of Thermal Biology 52:14-23. doi: $10.1016 /$ j.jtherbio.2015.05.002

Calosi P, Bilton DT, Spicer JI (2008) Thermal tolerance, acclimatory capacity and vulnerability to global climate change. Biology Letters 4:99-102. doi 10.1098/rsbl.2007.0408

Calosi P, Bilton DT, Spicer JI, et al (2010) What determines a species' geographical range? Thermal biology and latitudinal range size relationships in European diving beetles (Coleoptera: Dytiscidae). Journal of Animal Ecology 79:194-204. doi: 10.1111/j.1365-2656.2009.01611.x

Carrascal LM, Villén-Pérez S, Palomino D (2016) Preferred temperature and thermal breadth of birds wintering in peninsular Spain: the limited effect of temperature on species distribution. PeerJ 4:e2156. doi: 10.7717/peerj.2156

Carreira BM, Segurado P, Orizaola G, et al (2016) Warm vegetarians? Heat waves and diet shifts in tadpoles. Ecological Monographs 97:2964-2974. doi: $10.1002 /$ ecy. 1541

Chen I, Hill JK, Ohlemüller R, et al (2011) Rapid range shifts of species of climate warming. Science 333:1024-1026. doi: 10.1126/science.1206432

Chessman BC (2013) Identifying species at risk from climate change: Traits predict the drought vulnerability of freshwater fishes. Biological Conservation 160:40-49. doi: 10.1016/j.biocon.2012.12.032

Clarke A, O'Connor MI (2014) Diet and body temperature in mammals and birds. Global Ecology and Biogeography 23:1000-1008. doi: 10.1111/geb.12185

Cody ML (1966) A general theory of clutch size. Evolution 20:174-184

Coe SJ, Rotenberry JT (2003) WATER AVAILABILITY AFFECTS CLUTCH SIZE IN A DESERT SPARROW. Ecology 84:3240-3249

Corlett RT, Westcott DA (2013) Will plant movements keep up with climate change? Trends in Ecology \& Evolution 28:482-488. doi: 10.1016/j. tree.2013.04.003

Cormont A, Malinowska AH, Kostenko O, et al (2011) Effect of local weather on butterfly flight behaviour, movement, and colonisation: significance for dispersal under climate change. Biodiversity and Conservation 20:483-503. doi: 10.1007/s10531-010-9960-4

Dawson TP, Jackson ST, House JI, et al (2011) Beyond predictions: biodiversity conservation in a changing climate. Science (New York, NY) 332:53-58 doi: 10.1126/science. 1200303

Deeming DC, Ferguson MWJ (1992) Physiological effects of incubation temperature on embryonic development in reptiles and birds. Egg incubation: its effects on embryonic development in birds and reptiles (eds DC Deeming $\&$ MWJ Ferguson), pp. 147 173. Cambridge University Press, Cambridge.

Delattre T, Baguette M, Burel F, et al (2013) Interactive effects of landscape and weather on dispersal. Oikos 122:1576-1585. doi: 10.1111/j.16000706.2013.00123.x

Deutsch CA, Tewksbury JJ, Huey RB, et al (2008) Impacts of climate warming on terrestrial ectotherms across latitude. Proceedings of the National Academy of Sciences 105:6668-6672. doi: 10.1073/pnas.0709472105

Devictor V, Julliard R, Couvet D, Jiguet F (2008) Birds are tracking climate warming, but not fast enough. Proceedings Biological sciences / The Royal Society 275:2743-2748. doi: 10.1098/rspb.2008.0878

Devictor V, Van Swaay C, Brereton T, et al (2012) Differences in the climatic debts of birds and butterflies at a continental scale. Nature Climate Change 2:121-124. doi: 10.1038/nclimate1347 
Borges, F.J.A. et al

Diamond SE, Sorger DM, Hulcr J, et al (2012) Who likes it hot? A global analysis of the climatic, ecological, and evolutionary determinants of warming tolerance in ants. Global Change Biology 18:448-456. doi: 10.1111/j.13652486.2011.02542.x

Donnell SO, Logan CJ, Clayton NS (2012) Specialisations of birds that attend army ant raids: An ecological approach to cognitive and behavioral studies. Behavioural Processes 91:267-274. doi: 10.1016/j.beproc.2012.09.007

Duarte H, Tejedo M, Katzenberger M, et al (2012) Can amphibians take the heat? Vulnerability to climate warming in subtropical and temperate larval amphibian communities. Global Change Biology 18:412-421. doi: 10.1111/j.1365-2486.2011.02518.x

Duncan RP, Bomford M, Forsyth DM, Conibear L (2001) High predictability in introduction outcomes and the geographical range size of introduced Australian birds: a role for climate. Journal of Animal Ecology 70:621-632

Espinoza RE, Wiens JJ, Tracy CR (2004) Recurrent evolution of herbivory in small, cold-climate lizards: Breaking the ecophysiological rules of reptilian herbivory. Proceedings of the National Academy of Sciences 101:1681916824. doi: 10.1073 /pnas.0401226101

Estrada A, Meireles C, Morales-castilla I, et al (2015) Species' intrinsic traits inform their range limitations and vulnerability under environmental change. Global Ecology and Biogeography 849-858. doi: 10.1111/geb.12306

Estrada A, Morales-castilla I, Caplat P, Early R (2016) Usefulness of Species Traits in Predicting Range Shifts. Trends in Ecology \& Evolution 31:190 203. doi: $10.1016 /$ j.tree.2015.12.014

Evans KL, Duncan RP, Blackburn TM, Crick HQP (2005) Investigating geographic variation in clutch size using a natural experiment. Functional Ecology 19:616-624. doi: 10.1111/j.1365-2435.2005.01016.x

Fancourt BA, Hawkins CE, Nicol SC (2018) Mechanisms of climate-changeinduced species decline: spatial, temporal and long-term variation in the diet of an endangered marsupial carnivore, the eastern quoll. Wildlife Research 45:737-750. doi: 10.1071/WR18063

Farnsworth GL, Simons TR (2001) How many baskets? Clutch sizes that maximise annual fecundity of multiple-brooded birds. The Auk 118:973-982

Floeter SR, Behrens MD, Ferreira CEL, et al (2005) Geographical gradients of marine herbivorous fishes: patterns and processes. Marine Biology 147:1435-1447. doi: 10.1007/s00227-005-0027-0

Foden WB, Butchart SHM, Stuart SN, et al (2013) Identifying the World's Most Climate Change Vulnerable Species: A Systematic Trait-Based Assessment of all Birds, Amphibians and Corals. PLoS ONE 8:. doi: 10.1371/journal. pone. 0065427

Foden WB, Young BE, Akçakaya HR, et al (2018) Climate change vulnerability assessment of species. Wiley Interdisciplinary Reviews: Climate Change e551. doi: 10.1002/wcc.551

Folks DJ, Gann K, Fulbright TE, et al (2014) Drought but not population density influences dietary niche breadth in white-tailed deer in a semiarid environment. Ecosphere 5:1-15. doi: 10.1890/ES14-00196.1

Furness RW (1996) A review of seabird responses to natural and fisheriesinduced changes in food supply. In: Greenstreet SPR, Tasker ML (eds) Aquatic predators and their prey. Fishing News Books, Blackwell Science, Oxford, p 166-173

Garcia RA, Araújo MB, Burgess ND, et al (2014) Matching species traits to projected threats and opportunities from climate change. Journal of Biogeography 41:724-735. doi: 10.1111/jbi.12257

Gardali T, Seavy NE, Digaudio RT, Comrack LA (2012) A Climate Change Vulnerability Assessment of California' s At-Risk Birds. PLoS ONE 7:. doi: 10.1371/journal.pone.0029507

Gibbs HL (1988) Heritability and selection on clutch size in darwin's medium ground finches (Geospiza fortis). Evol 42:750-762

Gibbs HL, Grant PR (1987) ECOLOGICAL CONSEQUENCES OF AN EXCEPTIONALLY STRONG EL NINO EVENT ON DARWIN'S FINCHES. Ecology 68:1735-1746

Gienapp P, Teplitsky C, Alho JS, et al (2008) Climate change and evolution: disentangling environmental and genetic responses. Molecular Ecology 17:167-178. doi: 10.1111/j.1365-294X.2007.03413.x
González-Suarez M, Gomez A, Revilla E (2013) Which intrinsic traits predict vulnerability to extinction depends on the actual threatening processes. Ecosphere 4:1-16

Grant PR, Grant BR, Keller LF, Petren K (2000) Effects of El Nino events on Darwin's finch productivity. Ecology 81:2442-2457. doi: 10.1890/0012-9658(2000)081[2442:EOENOE]2.0.CO;2

Gray EL, Burwell CJ, Baker AM (2016) Benefits of being a generalist carnivore when threatened by climate change: The comparative dietary ecology of two sympatric semelparous marsupials, including a new endangered species (Antechinus arktos). Australian Journal of Zoology 64:249-261. doi: 10.1071/ZO16044

Griebeler EM, Caprano T, Bohning-Gaese K (2010) Evolution of avian clutch size along latitudinal gradients: do seasonality , nest predation or breeding season length matter? Journal of Evolutionary Biology 23:888-901. doi: 10.1111/j.1420-9101.2010.01958.x

Haywood S (1993) Sensory and hormonal control of clutch size in birds. Quarterly Review of Biology 68:33-51. doi: 10.1086/417910

Hero J-M, Williams SE, Magnusson WE (2005) Ecological traits of declining amphibians in upland areas of eastern Australia. Journal of Zoology 267:221-232. doi: 10.1017/S0952836905007296

Hill JK, Thomas CD, Fox R, et al (2002) Responses of butterflies to twentieth century climate warming: implications for future ranges. Proceedings of the Royal Society B: Biological Sciences 269:2163-2171. doi: 10.1098/ rspb.2002.2134

Hoffmann AA, Chown SL, Clusella-Trullas S (2013) Upper thermal limits in terrestrial ectotherms: How constrained are they? Functional Ecology 27:934-949. doi: 10.1111/j.1365-2435.2012.02036.x

Huey RB, Deutsch CA, Tewksbury JJ, et al (2009) Why tropical forest lizards are vulnerable to climate warming. Proceedings of the Royal Society B: Biological Sciences 276:1939-1948. doi: 10.1098/rspb.2008.19

Huey RB, Kearney MR, Krockenberger A, et al (2012) Predicting organismal vulnerability to climate warming: roles of behaviour, physiology and adaptation. Philosophical Transactions of the Royal Society B: Biological Sciences 367:1665-1679. doi: 10.1098/rstb.2012.0005

Huey RB, Losos JB, Moritz C (2010) Are Lizards Toast? Science 328:832-833. doi: $10.1126 /$ science. 1190374

Hurlbert AH, Liang Z (2012) Spatiotemporal Variation in Avian Migration Phenology: Citizen Science Reveals Effects of Climate Change. PLoS ONE 7:e31662. doi: 10.1371/journal.pone. 0031662

Husek J, Adamík P (2008) Long-term trends in the timing of breeding and brood size in the Red-Backed Shrike Lanius collurio in the Czech Republic, 19642004. Journal of Ornithology 149:97-103. doi: 10.1007/s10336-007-0222-5

Jarvinen A (1996) Correlation between egg size and clutch size in the Pied Flycatcher Bicedula hypoleuca in cold and warm summers. Ibis 138:620-623

Jarvinen A (1986) Clutch size of passerines in harsh environments. Oikos 46:365-371

Jetz W, Sekercioglu CH, Bohning-Gaese K (2008) The Worldwide Variation in Avian Clutch Size across Species and Space. PLoS Biology 6:e303. doi: 10.1371/journal.pbio.0060303

Jiguet F, Gadot A-S, Julliard R, et al (2007) Climate envelope, life history traits and the resilience of birds facing global change. Global Change Biology 1672-1684. doi: 10.1111/j.1365-2486.2007.01386.x

Jones T, Cresswell W (2010) The phenology mismatch hypothesis: are declines of migrant birds linked to uneven global climate change? Journal of Animal Ecology 79:98-108. doi: 10.1111/j.1365-2656.2009.01610.x

Karlsson B, Wiklund C (2005) Butterfly life history and temperature adaptations; dry open habitats select for increased fecundity and longevity. Journal of Animal Ecology 74:99-104. doi: 10.1111/j.1365-2656.2004.00902.x

Khaliq I, Böhning-Gaese K, Pfenninger M, et al (2017) The influence of thermal tolerances on geographical ranges of endotherms. Global Ecology and Biogeography 26:650-668. doi: 10.1111/geb.12575

Khaliq I, Fritz SA, Prinzinger R, et al (2015) Global variation in thermal physiology of birds and mammals: evidence for phylogenetic niche conservatism only in the tropics. Journal of Biogeography 42:2187-2196. doi: $10.1111 /$ jbi. 12573 
Khaliq I, Hof C, Prinzinger R, et al (2014) Global variation in thermal tolerances and vulnerability of endotherms to climate change. Proceedings of the Royal Society B: Biological Sciences 281:20141097. doi: 10.1098/rspb.2014.1097

Krause CM, Cobb NS, Pennington DD (2015) Range Shifts Under Future Scenarios of Climate Change: Dispersal Ability Matters for Colorado Plateau Endemic Plants. Natural Areas Journal 35:428-438. doi: $10.3375 / 043.035 .0306$

Kulesza G (1990) An analysis of clutch-size in New World passerine birds. Ibis 132:407-422

Lack D (1947) The significance of clutch-size. Part I - Intraespecific variation. Ibis 89:302-352

Lane JE, Kruuk LEB, Charmantier A, et al (2012) Delayed phenology and reduced fitness associated with climate change in a wild hibernator. Nature 489:554-557. doi: 10.1038/nature11335

Lehikoinen A, Ranta E, Pietiäinen H, et al (2011) The impact of climate and cyclic food abundance on the timing of breeding and brood size in four boreal owl species. Oecologia 349-355. doi: 10.1007/s00442-010-1730-1

Lehikoinen E, Sparks TH, Zalakevicius M (2004) Arrival and departure dates. Advances in Ecological Research 2504:. doi: 10.1016/S00652504(04)35001-4

Lenoir J, Svenning J (2015) Climate-related range shifts - a global multidimensional synthesis and new research directions. Ecography 38:15-28. doi: 10.1111/ecog.00967

Loarie SR, Duffy PB, Hamilton H, et al (2009) The velocity of climate change. Nature 462:1052-1055. doi: 10.1038/nature08649

Lovette IJ, Fitzpatrick JW (eds.) (2016) Handbook of bird biology. John Wiley \& Sons, Hoboken, NJ

Martin TE (1995) Avian Life History Evolution in Relation to Nest Sites, Nest Predation, and Food. Ecological Monographs 65:101-127

Martin TE, Martin PR, Olson CR, et al (2000) Parental Care and Clutch Sizes in North and South American Birds. Science 287:1482-1485

Massot M, Clobert J, Ferrière R (2008) Climate warming, dispersal inhibition and extinction risk. Global Change Biology 14:461-469. doi: 10.1111/j.13652486.2007.01514.x

Mckinney ML (1997) EXTINCTION VULNERABILITY AND SELECTIVITY : Combining Ecological and Paleontological Views. 495-516

McNab BK (2012) Extreme measures: the ecological energetics of birds and mammals. Chicago, IL: The University of Chicago Press

Methorst J, Böhning-Gaese K, Khaliq I, Hof C (2017) A framework integrating physiology, dispersal and land-use to project species ranges under climate change. Journal of Avian Biology 48:1532-1548. doi: 10.1111/jav.01299

Møller AP (2002) North Atlantic Oscillation (NAO) effects of climate on the relative importance of first and second clutches in a migratory passerine bird. Journal of Agricultural and Resource Economics 71:201-210

Møller AP, Flensted-Jensen E, Mardal W (2006) Dispersal and climate change: a case study of the Arctic tern Sterna paradisaea. Global Change Biology 12:2005-2013. doi: 10.1111/j.1365-2486.2006.01216.x

Møller AP, Rubolini D, Lehikoinen E (2008) Populations of migratory bird species that did not show a phenological response to climate change are declining. Proceedings of the National Academy of Sciences 105:1619516200. doi: $10.1073 /$ pnas. 0803825105

O’Donoghue M, Boutin S, Krebs CJ, et al (1998) Functional responses of coyotes and lynx to the snowshoe hare cycle. Ecology 79:1193-1208. doi: 10.1890/0012-9658(1998)079[1193:FROCAL]2.0.CO;2

Owens IPF, Bennett PM (2000) Ecological basis of extinction risk in birds: Habitat loss versus human persecution and introduced predators. Proceedings of the National Academy of Sciences 97:12144-12148. doi: 10.1073/ pnas. 200223397

Pacifici M, Foden WB, Visconti P, et al (2015) Assessing species vulnerability to climate change. Nature Climate Change 5:215-225. doi: 10.1038/ nclimate 2448

Pacifici M, Visconti P, Butchart SHM, et al (2017) Species' traits influenced their response to recent climate change. Nature Climate Change 7:205-208. doi: $10.1038 /$ nclimate 3223
Parmesan C (2006) Ecological and Evolutionary Responses to Recent Climate Change. Annual Review of Ecology, Evolution, and Systematics 37:637669. doi: 10.1146/annurev.ecolsys.37.091305.110100

Parmesan C, Yohe G (2003) A globally coherent fingerprint of climate change impacts across natural systems. Nature 421:37-42. doi: 10.1038/nature01286

Pärn H, Ringsby TH, Jensen H, Saether B-E (2012) Spatial heterogeneity in the effects of climate and density-dependence on dispersal in a house sparrow metapopulation. Proceedings of the Royal Society B: Biological Sciences 279:144-152. doi: 10.1098/rspb.2011.0673

Pearce-Higgins JW (2010) Using diet to assess the sensitivity of northern and upland birds to climate change. Climate Research 45:119-130. doi $10.3354 / \mathrm{cr} 00920$

Pearson RG (2006) Climate change and the migration capacity of species. Trends in Ecology and Evolution 21:111-113. doi: 10.1016/j.tree.2005.11.022

Pimm SL (1991) The balance of nature? Chicago: University of Chicago Press

Pöyry J, Luoto M, Heikkinen R, et al (2009) Species traits explain recent range shifts of Finnish butterflies. Global Change Biology 15:732-743. doi: 10.1111/j.1365-2486.2008.01789.x

Price T (1985) Reproductive responses to varying food supply in a population of Darwin's finches: Clutch size, growth rates and hatching synchrony. Oecologia 66:411-416

Przybylo R, Sheldon BC, Merila J (2000) Climatic effects on breeding and morphology: evidence for phenotypic plasticity. Journal of Animal Ecology 69:395-403

Purvis A, Hector A (2000) Getting the measure of biodiversity. Nature 405:212-219

Reside AE, Vanderwal J, Garnett ST, Kutt AS (2016) Vulnerability of Australian tropical savanna birds to climate change. Austral Ecology 41:106-116. doi: 10.1111/aec.12304

Reynolds SJ, Waldron S (1999) Body water dynamics at the onset of egg-laying in the Zebra Finch Taeniopygia guttata. Journal of Avian Biology 30:1-6. doi: $10.2307 / 3677236$

Ricklefs RE (1980) Geographical Variation in Clutch Size among Passerine Birds: Ashmole's Hypothesis. The Auk 97:38-49

Robinson H, Thayer J, Sydeman WJ, Weise M (2018) Changes in California sea lion diet during a period of substantial climate variability. Marine Biology 165:1-12. doi: 10.1007/s00227-018-3424-x

Roche EA, Gratto-Trevor CL, Goossen JP, White CL (2012) FLOODING AFFECTS DISPERSAL DECISIONS IN PIPING PLOVERS (CHARADRIUS MELODUS) IN PRAIRIE CANADA. The Auk 129:296306. doi: 10.1525/auk.2012.11196

Rubolini D, Møller AP, Rainio K, Lehikoinen E (2007) Intraspecific consistency and geographic variability in temporal trends of spring migration phenology among european bird species. Climate Research 35:135-146. doi: 10.3354/ cr00720

Rubolini D, Pirovano A, Borghi S (2003) Influence of seasonality, temperature and rainfall on the winter diet of the long-eared owl, Asio otus. Folia Zoologica 52:67-76

Rubolini D, Saino N, Møller AP (2010) Migratory behaviour constrains the phenological response of birds to climate change. Climate Research 42:45-55. doi: $10.3354 / \mathrm{cr} 00862$

Rugiu L, Manninen I, Sjöroos J, Jormalainen V (2018) Variations in tolerance to climate change in a key littoral herbivore. Marine Biology 165:1-11. doi: $10.1007 / \mathrm{s} 00227-017-3275-\mathrm{x}$

Saastamoinen M (2007) Life-history, genotypic, and environmental correlates of clutch size in the Glanville fritillary butterfly. Ecological Entomology $32: 235-242$

Schloss CA, Nuñez TA, Lawler JJ (2012) Dispersal will limit ability of mammals to track climate change in the Western Hemisphere. Proceedings of the National Academy of Sciences of the United States of America 109:86068611. doi: 10.1073/pnas. 1116791109

Schwartz MK, Copeland JP, Anderson NJ, et al (2009) Wolverine Gene Flow across a Narrow Climatic Niche. Ecology 90:3222-3232 
Borges, F.J.A. et al.

Sinervo B, Méndez-de-la-Cruz F, Miles DB, et al (2010) Erosion of lizard diversity by climate change and altered thermal niches. Science 328:894899. doi: 10.1126/science. 1184695

Skutch AF (1949) DO TROPICAL BIRDS REAR AS MANY YOUNG AS THEY CAN NOURISH? Ibis 91:430-455

Slagsvold T (1984) Clutch Size Variation of Birds in Relation to Nest Predation: On the Cost of Reproduction. Journal of Animal Ecology 53:945-953

Smith AP, Quin DG (1996) PATTERNS AND CAUSES OF EXTINCTION AND DECLINE IN AUSTRALIAN CONILURINE RODENTS. Biological Conservation 3207:243-267

Smith GR, Ballinger RE, Rose BR (1995) REPRODUCTION IN SCELOPORUS VIRGATUS FROM THE CHIRICAHUA MOUNTAINS OF SOUTHEASTERN ARIZONA WITH EMPHASIS ON ANNUAL VARIATION. Herpetologica 51:342-349

Somero GN (2011) Comparative physiology: a "crystal ball" for predicting consequences of global change. American Journal of Physiology: Regulatory, Integrative and Comparative Physiology 301:R1-R14. doi: 10.1152/ajpregu.00719.2010.

Sparks TH, Bairlein F, Bojarinova JG, et al (2005) Examining the total arrival distribution of migratory birds. Global Change Biology 11:22-30. doi: 10.1111/j.1365-2486.2004.00887.x

Stoleson SH (1999) The importance of the early onset of incubation for the maintenance of egg viability. Pages 600-613 in NJ Adams and RH Slotow (editors). Proceedings of the 22nd International Ornithological Congress. BirdLife South Africa, Johannesburg, South Africa

Stoleson SH, Beissinger SR (1999) Egg viability as a constraint on hatching synchrony at high ambient temperatures. Journal of Animal Ecology 68:951-962

Stutchbury BM, Morton ES (2001) Behavioral ecology of tropical birds. Academic Press, London, UK

Sunday JM, Bates AE, Dulvy NK (2012) Thermal tolerance and the global redistribution of animals. Nature Climate Change 2:686-690. doi: 10.1038/ nclimate 1539

Swanson DL, Palmer JS (2009) Spring migration phenology of birds in the Northern Prairie region is correlated with local climate change. Journal of Field Ornithology 80:351-363. doi: 10.1111/j.1557-9263.2009.00241.x

Tewksbury JJ, Huey RB, Deutsch CA (2008) Putting the Heat on Tropical Animals The Scale of Prediction. Science 320:1296-1297. doi: 10.1126/ science. 1159328

Thomas CD (2010) Climate, climate change and range boundaries. Diversity and Distributions 16:488-495. doi: 10.1111/j.1472-4642.2010.00642.x

Thorup K, Tøttrup AP, Rahbek C (2007) Patterns of phenological changes in migratory birds. Oecologia 151:697-703. doi: 10.1007/s00442-006-0608-8
Tøttrup AP, Rainio K, Coppack T, et al (2010) Local Temperature Fine-Tunes the Timing of Spring Migration in Birds. Integrative and Comparative Biology 50:293-304. doi: 10.1093/icb/icq028

Travis JMJ, Delgado M, Bocedi G, et al (2013) Dispersal and species' responses to climate change. Oikos 122:1532-1540. doi: 10.1111/j.16000706.2013.00399.x

Tryjanowski P, Kuzniak S, Sparks TIM (2002) Earlier arrival of some farmland migrants in western Poland. Ibis 144:62-68

Végvári Z, Bókony V, Barta Z, Kovács G (2010) Life history predicts advancement of avian spring migration in response to climate change. Global Change Biology 16:1-11. doi: 10.1111/j.1365-2486.2009.01876.x

Víkingsson GA, Elvarsson BP, Ólafsdóttir D, et al (2014) Recent changes in the diet composition of common minke whales (Balaenoptera acutorostrata) in Icelandic waters. A consequence of climate change? Marine Biology Research 10:138-152. doi: 10.1080/17451000.2013.793812

Violle C, Navas M, Vile D, et al (2007) Let the concept of trait be functional! Oikos 882-892. doi: 10.1111/j.2007.0030-1299.15559.x

Visser ME, Both C (2005) Shifts in phenology due to global climate change: The need for a yardstick. Proceedings of the Royal Society B: Biological Sciences 272:2561-2569. doi: 10.1098/rspb.2005.3356

Visser ME, Both C, Lambrechts MM (2004) Global Climate Change Leads to Mistimed Avian Reproduction. Advances in Ecological Research 35:89-110. doi: 10.1016/S0065-2504(04)35005-1

Visser ME, Noordwijk AJ Van, Tinbergen JM, Lessells CM (1998) Warmer springs lead to mistimed reproduction in great tits (Parus major). Proceedings of the Royal Society B: Biological Sciences 265:1867-1870

Walther G, Post E, Convey P, et al (2002) Ecological responses to recent climate change. Nature 389-395

Warren MS, Hill JK, Thomas JA, et al (2001) Rapid responses of British butterflies to opposing forces of climate and habitat change. Nature 414:65-69

Williams JE, Blois JL (2018) Range shifts in response to past and future climate change: Can climate velocities and species' dispersal capabilities explain variation in mammalian range shifts? Journal of Biogeography 45:21752189. doi: $10.1111 /$ jbi.13395

Williams SE, Shoo LP, Isaac JL, et al (2008) Towards an Integrated Framework for Assessing the Vulnerability of Species to Climate Change. PLoS Biology 6.. doi: 10.1371/journal.pbio.0060325

Received: 18/02/2021

Revised: 02/06/2021

Accepted: 10/06/2021

Published online: 09/07/2021 